\title{
Association between insulin resistance and lung function change: Analysis from the community- based prospective Ansan-Ansung cohort in Korea
}

\section{Sang Hyuk Kim}

Republic of Korea Army Headquarters https://orcid.org/0000-0002-0410-8524

Hyang Ki Min

Eulji General Hospital: Eulji Hospital

Hyun Sam Kim

Eulji General Hospital: Eulji Hospital

Sung Woo Lee ( $\nabla$ neplsw@gmail.com )

Eulji General Hospital: Eulji Hospital https://orcid.org/0000-0002-4419-3938

Research article

Keywords: Diabetes mellitus, Lung, Insulin resistance, Spirometry

Posted Date: November 4th, 2020

DOI: https://doi.org/10.21203/rs.3.rs-101239/v1

License: (9) This work is licensed under a Creative Commons Attribution 4.0 International License. Read Full License

Version of Record: A version of this preprint was published at BMC Pulmonary Medicine on April 1st, 2021. See the published version at https://doi.org/10.1186/s12890-021-01478-7. 


\section{Abstract}

Background. Diabetes mellitus and hyperglycemia are associated with respiratory dysfunction. Although several studies have reported that insulin resistance is related to decreased lung function, the association between insulin resistance and lung function changes has been rarely studied. This study aimed to investigate the effect of insulin resistance on the annual lung function change using a large-scale prospective cohort.

Methods. We analyzed a community-based prospective cohort in Korea comprising 7,536 participants whose serial lung functions were assessed. Exposure was baseline insulin resistance estimated with homeostatic model assessment-insulin resistance (HOMA-IR), and outcomes were annual changes in forced expiratory volume in 1 second (FEV1), functional vital capacity (FVC), and FEV1/FVC ratio.

Results. In the multivariate linear regression, the increased in the logarithmic HOMA-IR was associated with a decrease in FEV1 ( $\beta$ : $-0.23 ; 95 \% \mathrm{Cl}:-0.32$ to $-0.13 ; P<0.001)$, and FVC $(\beta:-0.29 ; 95 \% \mathrm{Cl}:-0.39$ to $-0.19 ; P<0.001)$, but not in FEV1/FVC ratio $(\beta: 0.05 ; 95 \% \mathrm{Cl}: 0.00$ to $0.11 ; P=0.051)$. In the generalized additive model plot, L-shaped association between HOMA-IR and changes in FEV1 and FVC were observed with a HOMA-IR threshold of 2.4. Age modulated the effect of HOMA-IR on the change in FEV1, and increased HOMA-IR was associated with decreased annual FEV1 change only in the older population.

Conclusions. Insulin resistance was a novel risk factor for the decrease in FEV1 and FVC. The aging process may modulate the effect of insulin resistance on the decline in lung function.

\section{Background}

Diabetes mellitus is a prevalent chronic disease in modern society, with many experiencing diabetes and its complications [1, 2]. Lung function decline has been considered a major complication of diabetes [35]. Several studies have found that diabetes and hyperglycemia are associated with the development of various pulmonary diseases, including chronic obstructive pulmonary disease, asthma, and interstitial lung disease [6-8]. Therefore, good control of diabetes may prevent future lung diseases.

Increased insulin resistance has been associated with the future development of obesity, diabetes [9], cardiovascular diseases [10], neurologic impairment [11], and kidney dysfunction [12]. Although several studies have reported the potential association between insulin resistance and decreased lung function, none of these studies have evaluated the longitudinal effect of insulin resistance on future lung function changes. The aging process can cause diverse physiological, immunological and structural changes in the respiratory system $[13,14]$. Thus, analyzing consecutive measurements of lung function may help to interpret the effects of aging on insulin resistance and lung function changes. In addition, it can clarify a causal association between insulin resistance and lung function.

Since diabetes is associated with a future decline in lung function and insulin resistance is a fundamental pre-condition of diabetes, we hypothesized that increased insulin resistance may be 
associated with future decline in lung function. Therefore, this study aimed to investigate the association between insulin resistance and lung function change using data from a community-based prospective Ansan-Ansung cohort in Korea.

\section{Methods}

\section{Participants}

The Ansan-Ansung cohort comprise participants aged 40-69 years who lived in Ansan (urban) and Ansung (rural) areas, and this cohort was analyzed to determine the factors affecting the incidence of chronic diseases. Baseline measurements were performed between May 2001 and February 2003, and two subsequent lung function tests were performed biennially thereafter. More detailed information about the Ansan-Ansung cohort can be obtained in previous reports [15]. Of the 10,030 participants, we excluded 134 missing smoking status, 188 missing socioeconomic status, and 316 missing metabolic disorders. Of the 9,392, participants, 1,856 with missing additional lung function test results were further excluded. Therefore, 7,536 participants were finally included in this analysis (Fig. 1).

\section{Exposure :insulin resistance}

Insulin resistance was assessed using the homeostatic model assessment-insulin resistance (HOMA-IR). HOMA-IR was calculated using the following equation: fasting insulin $(\mu \mathrm{IU} / \mathrm{mL}) \times$ fasting glucose $(\mathrm{mg} / \mathrm{dL}) / 405[16]$.

\section{Outcomes: Changes in lung function test}

Lung function tests were performed using a spirometer (VMAX2130; Sensormedics Corporation, Yorba, CA, USA). Pre-bronchodilator values were measured 3 times by trained technicians and the best scores were recorded. Predicted values of functional vital capacity (FVC) and functional expiratory volume in 1 second (FEV1) were calculated using the Korean formula [17]. The FEV1/FVC ratio was expressed as the percentage of FEV1 divided by FVC. Study outcomes were annual changes in FEV1, FVC, and FEV1/FVC ratio. These values were determined by calculating the regression coefficient using a least-square linear regression analysis, with FEV1, FVC, and FEV1/FVC ratio as functions of time in years. It was applied to all values of FEV1, FVC, and FEV1/FVC ratio that were obtained during the follow-up period.

\section{Measurements and other definitions}

Trained investigators interviewed participants regarding their socioeconomic status and lifestyle habits using KoGES Baseline Core Questionnaire. High income was defined as the highest quintile of monthly household income ( $\geq 3$ million won a month). Blood pressure (BP) was defined as the average BP on both arms using a standard mercury sphygmomanometer (Baumanometer-Standby; W. A. Baum Co., Inc., Copiague, NY, USA). Body mass index (BMI) was defined by dividing the weight by the square of the height $\left(\mathrm{kg} / \mathrm{m}^{2}\right)$. Waist circumference was measured at the narrowest point between the lower rib and the iliac crest (measured to the nearest $0.1 \mathrm{~cm}$ ). All blood samples were examined after fasting for at least 8 hours. Hemoglobin level and white blood cell (WBC) count were analyzed using enzymatic methods with 
ADVIA 120 (Bayer Diagnostics, Tarrytown, NY, USA). Fasting glucose, hemoglobin $\mathrm{A}_{1} \mathrm{c}\left(\mathrm{HbA}_{1} \mathrm{c}\right)$, triglyceride, high density lipoprotein (HDL) cholesterol, C-reactive protein (CRP), and serum creatinine levels were measured using ADVIA 1650 (Siemens, Tarrytown, NY, USA). Estimated glomerular filtration rate (eGFR) was defined using the Chronic Kidney Disease Epidemiology Collaboration equation [18].

\section{Statistical analyses}

Normality of distribution of continuous variables was assessed using histogram and Q-Q plots. Mean \pm standard deviation (SD) was used to express normally distributed continuous variables, whereas median with interquartile range (IQR) was used for non-normally distributed continuous variables. The $P$ trend was analyzed using linear regression for the normally distributed continuous variables, the JonckheereTerpstra test for the non-normally distributed continuous variables, and the Cochran-Armitage test for categorical variables.

The simple associations between HOMA-IR and spirometric parameters were expressed using the locally weighted scatterplot smoothing (LOWESS) function. In multivariate analyses, covariates were chosen based on clinical and statistical relevance. The non-linear association between HOMA-IR and changes in FEV1 and FVC was analyzed using the multivariate generalized additive model (GAM) for Gaussian distributions with the "mgcv" package, and calculation of Akaike information criterion (AIC) was used for the model fitting. In AIC, lower scores within the data set indicate a better model fit [19]. The threshold point of HOMA-IR was chosen based on the best fit determined by AIC among the models.

In the subgroup analysis, clinically significant variables were chosen, and participants were divided by the median of variables. The modulatory effect was confirmed by adding the interaction term of variables defining the subgroup to the multivariate linear regression analysis. To visualize potential interaction of age on the association between insulin resistance and annual lung function change, the LOWESS regression with interaction was implemented using the "predict3d" package. A $P$ value $<0.05$ was considered statistically significant. All statistical analyses were performed using $\mathrm{R}$ version 3.6.2 ( $\mathrm{R}$ Core Team 2019; R Foundation for Statistical Computing, Vienna, Austria).

\section{Results}

The mean age of the 7,536 participants was 51.7 years, $49.2 \%$ were men, and $41.7 \%$ were current or past smoker. The mean \pm SD of BMI, systolic and diastolic BP, waist circumference, HDL cholesterol level, eGFR, hemoglobin level, and WBC count were $24.6 \pm 3.1 \mathrm{~kg} / \mathrm{m}^{2}, 120.9 \pm 18.0 \mathrm{mmHg}, 80.2 \pm 11.3 \mathrm{mmHg}$, $82.7 \pm 8.7 \mathrm{~cm}, 44.6 \pm 9.9 \mathrm{~mL} / \mathrm{dL}, 94.1 \pm 13.3 \mathrm{~mL} / \mathrm{min} / 1.73 \mathrm{~m}^{2}, 13.6 \pm 1.6 \mathrm{~g} / \mathrm{dL}$, and $6.5 \pm 1.8 \times 10^{3} / \mu \mathrm{L}$, respectively. Moreover, the median (IQR) of fasting glucose, $\mathrm{HbA}_{1} \mathrm{c}$, triglyceride levels, and CRP levels were 82 (77-91) mg/dL, 5.6 (5.3-5.9) \%, 135 (100-189) mg/dL, and $0.14(0.07-0.24) \mathrm{mg} / \mathrm{dL}$, respectively. At baseline, the mean \pm SD values of FEV1, FVC, and FEV1/FVC ratio were $97.0 \pm 13.8 \%$ predicted, $96.9 \pm$ $13.0 \%$ predicted, and $80.1 \pm 7.4 \%$, respectively. The mean \pm SD values of annual change in FEV1, FVC, and FEV1/FVC ratio were $-0.55 \pm 2.54 \%$ predicted/year, $-0.56 \pm 2.65 \%$ predicted/year, and $-0.37 \pm 1.44 \% /$ year, respectively. 
The clinical characteristics of the study population according to HOMA-IR quartile are shown in Table 1. Although age was not associated with HOMA-IR quartile, increased HOMA-IR quartile was associated with decreased proportion of men. Although income and educational status were not associated with HOMAIR quartile, increased HOMA-IR quartile was associated with a decreased rate of current or past smoking. With the increase of HOMA-IR quartile, BMI, systolic and diastolic BP, waist circumference, WBC count, and fasting glucose, $\mathrm{HbA}_{1} \mathrm{c}$, triglyceride, hemoglobin, and CRP levels increased, whereas HDL cholesterol levels decreased. With the increase of HOMA-IR quartile, baseline percent-predicted FEV1 and percentpredicted FVC decreased, but FEV1/FVC increased. 
Table 1

Clinical characteristics of the study population according to HOMA-IR quartile.

\section{HOMA-IR groups $(n=7536)$}

\begin{tabular}{|c|c|c|c|c|c|}
\hline & $\begin{array}{l}\text { 1Q: }<1.05(\mathrm{n} \\
=1888)\end{array}$ & $\begin{array}{l}2 Q: 1.06-1.45 \\
(n=1887)\end{array}$ & $\begin{array}{l}3 \mathrm{Q}: 1.45-2.03 \\
(\mathrm{n}=1882)\end{array}$ & $\begin{array}{l}4 \mathrm{Q}: \geq 2.03(\mathrm{n} \\
=1879)\end{array}$ & $\begin{array}{l}P \text { - } \\
\text { trend }\end{array}$ \\
\hline Age(years) & $52.09 \pm 8.86$ & $51.56 \pm 8.73$ & $51.43 \pm 8.60$ & $51.56 \pm 8.63$ & 0.099 \\
\hline Male, n (\%) & $\begin{array}{l}1043 \\
(55.24 \%)\end{array}$ & $930(49.28 \%)^{\star}$ & $852(45.27 \%)^{*} \dagger$ & $\begin{array}{l}884 \\
(47.05 \%) *\end{array}$ & <. 001 \\
\hline High income, n (\%) & $\begin{array}{l}337 \\
(17.85 \%)\end{array}$ & $343(18.18 \%)$ & 335 (17.80\%) & $376(20.01 \%)$ & 0.127 \\
\hline $\begin{array}{l}\text { College graduate, } \\
\mathrm{n}(\%)\end{array}$ & $\begin{array}{l}261 \\
(13.82 \%)\end{array}$ & $263(13.94 \%)$ & $279(14.82 \%)$ & $283(15.06 \%)$ & 0.204 \\
\hline $\begin{array}{l}\text { Current or past } \\
\text { smoker, } \mathrm{n}(\%)\end{array}$ & $\begin{array}{l}865 \\
(45.82 \%)\end{array}$ & $781(41.39 \%)^{\star}$ & $723(38.42 \%)^{\star}$ & $\begin{array}{l}775 \\
(41.25 \%)^{*}\end{array}$ & 0.001 \\
\hline $\mathrm{BMI}\left(\mathrm{Kg} / \mathrm{m}^{2}\right)$ & $23.57 \pm 2.98$ & $23.96 \pm 2.84 *$ & $24.84 \pm 2.79 * \dagger$ & $\begin{array}{l}26.16 \pm \\
3.08^{*}+\ddagger\end{array}$ & <. 001 \\
\hline $\begin{array}{l}\text { Systolic BP } \\
(\mathrm{mmHg})\end{array}$ & $\begin{array}{l}118.13 \pm \\
17.31\end{array}$ & $118.91 \pm 17.05$ & $\begin{array}{l}121.01 \pm \\
17.96 *+\end{array}$ & $\begin{array}{l}125.50 \pm \\
18.92^{*} † \ddagger\end{array}$ & <. 001 \\
\hline $\begin{array}{l}\text { Diastolic BP } \\
(\mathrm{mmHg})\end{array}$ & $\begin{array}{l}78.38 \pm \\
11.14\end{array}$ & $79.00 \pm 11.01$ & $80.40 \pm 11.14^{\star}+$ & $\begin{array}{l}83.10 \pm \\
11.44^{\star}+\ddagger\end{array}$ & $\grave{0}_{0.001}$ \\
\hline $\begin{array}{l}\text { Waist } \\
\text { circumference } \\
(\mathrm{cm})\end{array}$ & $79.92 \pm 8.41$ & $80.84 \pm 8.04$ * & $83.07 \pm 8.15^{\star}+$ & $\begin{array}{l}86.89 \pm \\
8.33^{*} † \neq\end{array}$ & <. 001 \\
\hline $\begin{array}{l}\text { Fasting glucose } \\
\text { (mg/dL) }\end{array}$ & $79(75-85)$ & $82(77-87)^{\star}$ & $83(78-90) *+$ & $\begin{array}{l}90(82- \\
101) *+\ddagger\end{array}$ & $\dot{0} 001$ \\
\hline HbA1c (\%) & $5.5(5.3-5.7)$ & $5.5(5.3-5.8)$ & $5.6(5.3-5.8)^{\star} \dagger$ & $\begin{array}{l}5.7(5.5-6.3) \\
\star+\neq\end{array}$ & $\begin{array}{l}<.001 \\
0.001\end{array}$ \\
\hline $\begin{array}{l}\text { Triglyceride } \\
(\mathrm{mg} / \mathrm{dL})\end{array}$ & $\begin{array}{l}122(93- \\
169)\end{array}$ & $124(95-171)$ & $\begin{array}{l}136(101- \\
188)^{\star+}\end{array}$ & $\begin{array}{l}162(118- \\
231)^{\star+\neq \ddagger}\end{array}$ & <. 001 \\
\hline
\end{tabular}

Values are expressed as mean \pm standard deviation for normally distributed continuous variables, median and interquartile range for non-normally distributed variables and percentage for categorical variables. $P$-trend was analyzed normally distributed continuous variables by the linear regression, for non-normally distributed continuous variable by Jonckheere-Terpstra tests, and for categorical variables by Cochran-Armitage test for trend. *, $\dagger$, and $\neq$ meant $P<0.05$ when compared to $<1.05$, $1.06-1.45,1.45-2.03$ groups of HOMA-IR, respectively, using Bonferroni post-hoc analysis of one-way ANOVA for normally distributed continuous variables, Mann-Whitney U tests for non-normally distributed continuous variable, and chi-square tests for categorical variables. Abbreviations: HOMA$\mathrm{IR}$, homeostatic model assessment for insulin resistance; $\mathrm{BMI}$, body mass index; $\mathrm{BP}$, blood pressure; $\mathrm{HbA}_{1} \mathrm{C}$, hemoglobin $\mathrm{A}_{1} \mathrm{C} ; \mathrm{HDL}$, high density lipoprotein; eGFR, estimated glomerular filtration rate; WBC, white blood cell; CRP, C-reactive protein; FEV1, forced expiratory volume in 1 second; FVC, functional vital capacity. 


\section{HOMA-IR groups $(n=7536)$}

\begin{tabular}{|c|c|c|c|c|c|}
\hline $\begin{array}{l}\text { HDL cholesterol } \\
(\mathrm{mg} / \mathrm{dL})\end{array}$ & $\begin{array}{l}46.06 \pm \\
10.17\end{array}$ & $45.86 \pm 10.13$ & $44.10 \pm 9.61^{*}+$ & $\begin{array}{l}42.30 \pm \\
9.00 *+\ddagger\end{array}$ & $\stackrel{<}{<.001}$ \\
\hline $\begin{array}{l}\text { eGFR } \\
\left(\mathrm{mL} / \mathrm{min} / 1.73 \mathrm{~m}^{2}\right)\end{array}$ & & ? & & 3 & 0.278 \\
\hline $\begin{array}{l}\text { Hemoglobin } \\
\text { (g/dL) }\end{array}$ & 68 & $13.55 \pm$ & $13.55 \pm$ & & $\dot{0} 001$ \\
\hline $\begin{array}{l}\text { WBC count }\left(\times 10^{3} /\right. \\
\mu \mathrm{L})\end{array}$ & $6.43 \pm 1.80$ & $6.38 \pm 1.71$ & $6.46 \pm 1$ & & $<.001$ \\
\hline CRP I & $\begin{array}{l}0.12(0.05- \\
0.22)\end{array}$ & $\begin{array}{l}0.13(0.06- \\
0.23)\end{array}$ & & & $<$. \\
\hline Baseline FEV1 (L) & $2.96 \pm 0.68$ & $2.96 \pm 0.69$ & $2.92 \pm 0.70$ & $2.91 \pm 0.69$ & 0.024 \\
\hline Baseline FVC (L) & $3.74 \pm 0.84$ & $3.72 \pm 0.88$ & $3.66 \pm 0.88^{*}$ & $3.63 \pm$ & $\dot{0.001}$ \\
\hline $\begin{array}{l}\text { Baseline FEV1 (\%- } \\
\text { predicted) }\end{array}$ & $\begin{array}{l}96.82 \pm \\
14.01\end{array}$ & $97.82 \pm 1$ & $97.38 \pm 13.78$ & $\begin{array}{l}96.02 \pm \\
13.42 \ddagger \ddagger\end{array}$ & $\dot{c}_{0.001}$ \\
\hline $\begin{array}{l}\text { Baseline FVC (\%- } \\
\text { predicted) }\end{array}$ & $\begin{array}{l}97.45 \pm \\
12.76\end{array}$ & $98.25 \pm 13.25$ & $97.08 \pm 13.16 \dagger$ & & $\dot{0} .001$ \\
\hline $\begin{array}{l}\text { Baseline } \\
\text { FEV1/FVC (\%) }\end{array}$ & $79.60 \pm 7.91$ & $79.97 \pm 7.42$ & $80.29 \pm 7.26$ * & $80.48 \pm 6.89 *$ & 0.001 \\
\hline \multicolumn{6}{|c|}{$\begin{array}{l}\text { Values are expressed as mean } \pm \text { standard deviation for normally distributed continuous variables, } \\
\text { median and interquartile range for non-normally distributed variables and percentage for categorical } \\
\text { variables. } P \text {-trend was analyzed normally distributed continuous variables by the linear regression, for } \\
\text { non-normally distributed continuous variable by Jonckheere-Terpstra tests, and for categorical } \\
\text { variables by Cochran-Armitage test for trend. *, }+ \text {, and } ¥ \text { meant } P<0.05 \text { when compared to }<1.05 \text {, } \\
1.06-1.45,1.45-2.03 \text { groups of HOMA-IR, respectively, using Bonferroni post-hoc analysis of one-way } \\
\text { ANOVA for normally distributed continuous variables, Mann-Whitney U tests for non-normally } \\
\text { distributed continuous variable, and chi-square tests for categorical variables. Abbreviations: HOMA- } \\
I_{R} \text {, homeostatic model assessment for insulin resistance; BMI, body mass index; BP, blood pressure; } \\
\mathrm{HbA}_{1} \mathrm{C} \text {, hemoglobin } \mathrm{A}_{1} \mathrm{C} \text {; HDL, high density lipoprotein; eGFR, estimated glomerular filtration rate; WBC, } \\
\text { white blood cell; CRP, C-reactive protein; FEV1, forced expiratory volume in } 1 \text { second; FVC, functional } \\
\text { vital capacity. }\end{array}$} \\
\hline
\end{tabular}

We explored the association between HOMA-IR and annual changes in lung function test (Fig. 2). As HOMA-IR increased, annual FEV1 and FVC change decreased, whereas annual FEV1/FVC ratio change increased. Although the negative association between HOMA-IR and annual changes in FEV1 and FVC was statistically significant, the association between HOMA-IR and FEV1/FVC ratio was nullified in the multivariate linear regression analysis (Table 2). In the multivariate GAM plot analysis, we identified that the association between HOMA-IR and annual change in FEV1 and FVC was L-shaped, and the lowest AICs were found in HOMA-IR 2.4, in both annual FEV1 and FVC (Fig. 3). 
Table 2

Association between log-transformed HOMA-IR and the annual lung function change.

\begin{tabular}{|c|c|c|c|c|c|c|}
\hline & \multicolumn{6}{|c|}{ Per 1 unit increase of Log-HOMA-IR } \\
\hline & \multicolumn{2}{|l|}{ Univariate } & \multicolumn{2}{|l|}{ Model 1} & \multicolumn{2}{|l|}{ Model 2} \\
\hline Outcomes & Beta $(95 \% \mathrm{Cl})$ & $P$ & Beta $(95 \% \mathrm{Cl})$ & $P$ & Beta $(95 \% \mathrm{Cl})$ & $P$ \\
\hline $\begin{array}{l}\Delta \text { FEV1 (\%- } \\
\text { predicted/year) }\end{array}$ & $\begin{array}{l}-0.15(-0.24 \text { to } \\
-0.06)\end{array}$ & $<.001$ & $\begin{array}{l}-0.15(-0.24 \text { to } \\
-0.07)\end{array}$ & $<.001$ & $\begin{array}{l}-0.23(-0.32 \text { to } \\
-0.13)\end{array}$ & $<.001$ \\
\hline $\begin{array}{l}\Delta \text { FVC (\%- } \\
\text { predicted/year) }\end{array}$ & $\begin{array}{l}-0.20(-0.29 \text { to } \\
-0.11)\end{array}$ & $<.001$ & $\begin{array}{l}-0.20(-0.29 \text { to } \\
-0.11)\end{array}$ & <. 001 & $\begin{array}{l}-0.29(-0.39 \text { to } \\
-0.19)\end{array}$ & $\dot{0}_{0.001}$ \\
\hline $\begin{array}{l}\Delta \text { FEV1/FVC } \\
\text { (\%/year) }\end{array}$ & $\begin{array}{l}0.07 \text { ( } 0.02 \text { to } \\
0.12)\end{array}$ & 0.004 & $\begin{array}{l}0.06(0.02 \text { to } \\
0.11)\end{array}$ & 0.010 & $\begin{array}{l}0.05 \text { (0.00 to } \\
0.11)\end{array}$ & 0.051 \\
\hline \multicolumn{7}{|c|}{$\begin{array}{l}\text { In model 1, age and sex were added as covariates. Model } 2 \text { included high income, college graduate, } \\
\text { smoking status, BMI, waist circumference, systolic and diastolic BP, triglyceride, HDL cholesterol, } \\
\text { eGFR, WBC count, hemoglobin and CRP levels in addition to the covariates in the model } 1 \text {. } \\
\text { Abbreviations: HOMA-IR, homeostatic model assessment for insulin resistance; Cl, confidence interval } \\
\text { FEV1, forced expiratory volume in } 1 \text { second; FVC, forced vital capacity. }\end{array}$} \\
\hline
\end{tabular}

There were no subgroups showing the effect modification between HOMA-IR and annual FVC change. However, participant age significantly modified the effect of HOMA-IR on annual FEV1 change ( $P$ for interaction $<0.001$ ). Although HOMA-IR was not associated with annual FEV1 change in people aged $<50$ years, increased HOMA-IR was significantly associated with decreased annual FEV1 change in individuals aged $\geq 50$ years (Table 3 ). We also identified similar effect modification of age on the association between HOMA-IR and annual FEV1 change in the LOWESS regression plot with interaction (Fig. 4). 
Table 3

Subgroup analysis for the effects of HOMA-IR on the annual rates of changes in FEV1 and FVC.

\section{Per 1 unit increase of Log-HOMA-IR}

\begin{tabular}{|c|c|c|c|c|c|}
\hline \multirow[b]{2}{*}{ Subgroup } & \multicolumn{3}{|c|}{ Adjusted beta $(95 \% \mathrm{Cl}, P)$} & \multicolumn{2}{|c|}{$\begin{array}{l}P \text { for } \\
\text { interaction }\end{array}$} \\
\hline & No. of people & $\begin{array}{l}\Delta \text { FEV1 (\%- } \\
\text { predicted/year) }\end{array}$ & $\begin{array}{l}\Delta \text { FVC (\%- } \\
\text { predicted/year) }\end{array}$ & $\stackrel{\Delta}{\mathrm{FEV} 1}$ & $\begin{array}{l}\Delta \\
\text { FVC }\end{array}$ \\
\hline \multirow[t]{2}{*}{ Age (years) } & $\begin{array}{l}<50(n= \\
3,755)\end{array}$ & $\begin{array}{l}-0.03(-0.16 \text { to } 0.09 \\
0.597)\end{array}$ & $\begin{array}{l}-0.14(-0.27 \text { to } 0.02 \\
0.026)\end{array}$ & $<.001$ & 0.144 \\
\hline & $\begin{array}{l}\geq 50(\mathrm{n}= \\
3,781)\end{array}$ & $\begin{array}{l}-0.37(-0.51 \text { to }-0.23 \\
<0.001)\end{array}$ & $\begin{array}{l}-0.38(-0.53 \text { to }-0.24 \\
<0.001)\end{array}$ & & \\
\hline \multirow[t]{2}{*}{ Sex } & $\begin{array}{l}\text { Male }(\mathrm{n}= \\
3,709)\end{array}$ & $\begin{array}{l}-0.25(-0.37 \text { to }-0.12 \\
<0.001)\end{array}$ & $\begin{array}{l}-0.26(-0.39 \text { to }-0.12 \\
<0.001)\end{array}$ & 0.585 & 0.306 \\
\hline & $\begin{array}{l}\text { Female }(n= \\
3,827)\end{array}$ & $\begin{array}{l}-0.23(-0.37 \text { to }-0.09 \\
0.001)\end{array}$ & $\begin{array}{l}-0.33(-0.47 \text { to }-0.19 \\
<0.001)\end{array}$ & & \\
\hline \multirow[t]{2}{*}{$\begin{array}{l}\text { Current or past } \\
\text { smoker }\end{array}$} & $\begin{array}{l}\text { No }(n= \\
4,392)\end{array}$ & $\begin{array}{l}-0.20(-0.32 \text { to }-0.07 \\
0.002)\end{array}$ & $\begin{array}{l}-0.31(-0.44 \text { to }-0.18 \\
<0.001)\end{array}$ & 0.912 & 0.309 \\
\hline & $\begin{array}{l}\text { Yes }(n= \\
3,144)\end{array}$ & $\begin{array}{l}-0.29(-0.44 \text { to }-0.15 \\
<0.001)\end{array}$ & $\begin{array}{l}-0.27(-0.42 \text { to }-0.12 \\
<0.001)\end{array}$ & & \\
\hline \multirow[t]{2}{*}{$\mathrm{BMI}\left(\mathrm{kg} / \mathrm{m}^{2}\right)$} & $\begin{array}{l}<25(n= \\
4,277)\end{array}$ & $\begin{array}{l}-0.25(-0.38 \text { to }-0.13 \\
<0.001)\end{array}$ & $\begin{array}{l}-0.30(-0.43 \text { to }-0.17 \\
<0.001)\end{array}$ & 0.289 & 0.704 \\
\hline & $\begin{array}{l}\geq 25(\mathrm{n}= \\
3,259)\end{array}$ & $\begin{array}{l}-0.20(-0.34 \text { to }-0.05 \\
0.008)\end{array}$ & $\begin{array}{l}-0.27(-0.42 \text { to }-0.12 \\
<0.001)\end{array}$ & & \\
\hline \multirow[t]{2}{*}{$\begin{array}{l}\text { WBC count } \\
\left(x 10^{3} / \mu \mathrm{L}\right)\end{array}$} & $\begin{array}{l}<6.3(\mathrm{n}= \\
3,693)\end{array}$ & $\begin{array}{l}-0.19(-0.34 \text { to }-0.04 \\
0.011)\end{array}$ & $\begin{array}{l}-0.29(-0.43 \text { to }-0.14 \\
<0.001)\end{array}$ & 0.683 & 0.772 \\
\hline & $\begin{array}{l}\geq 6.3(n= \\
3,843)\end{array}$ & $\begin{array}{l}-0.26(-0.39 \text { to }-0.14 \\
<0.001)\end{array}$ & $\begin{array}{l}-0.29(-0.43 \text { to }-0.16 \\
<0.001)\end{array}$ & & \\
\hline \multirow[t]{2}{*}{$\begin{array}{l}\text { Hemoglobin } \\
(\mathrm{mg} / \mathrm{dL})\end{array}$} & $\begin{array}{l}<13.6(n= \\
3,668)\end{array}$ & $\begin{array}{l}-0.23(-0.38 \text { to }-0.08 \\
0.002)\end{array}$ & $\begin{array}{l}-0.31(-0.47 \text { to }-0.16 \\
<0.001)\end{array}$ & 0.442 & 0.389 \\
\hline & $\begin{array}{l}\geq 13.6(n= \\
3,449)\end{array}$ & $\begin{array}{l}-0.23(-0.35 \text { to }-0.11 \\
<0.001)\end{array}$ & $\begin{array}{l}-0.27(-0.40 \text { to }-0.15 \\
<0.001)\end{array}$ & & \\
\hline
\end{tabular}

Adjusted beta and $95 \%$ Cls were analyzed using the multivariate linear regression. All covariates of model 2 shown in Table 2 were included for adjustment. The variable used to divide subgroup was excluded. Abbreviations: HOMA-IR, homeostatic model assessment for insulin resistance; $\mathrm{Cl}$, confidence interval; BMI, body mass index; WBC, white blood cell; FEV1, forced expiratory volume in 1 second; FVC, functional vital capacity.

\section{Discussion}


Recently, decreased lung function has been suggested as a complication of insulin resistance. In their large-scale cross-sectional study, Lawlor et al. found that HOMA-IR decreased by $5 \%$ and $8 \%$ for a 1 SD increase in log FEV1 and FVC, respectively [20]. Sagun et al. also showed that decreased percentpredicted FEV1 was correlated with increased insulin resistance (HOMA-IR $\geq 2.5)$ in an age-adjusted analysis (OR 0.97, 95\% $\mathrm{Cl} 0.94-1.00, P=0.028)$ [21]. However, most previous studies were crosssectional, and a causal association between insulin resistance and decreased lung function needed to be evaluated in a prospective cohort. Therefore, we conducted the current study using a prospective community-based cohort and found that increased insulin resistance was associated with a decline in lung function, particularly in the elderly population.

In the current study, we found that increased baseline HOMA-IR was associated with a decrease in FEV1 and FVC, but not in FEV1/FVC ratio, in the multivariate analysis after adjusting for possible confounders. We also found an L-shaped association between HOMA-IR and annual changes in FEV1 and FVC using the multivariate GAM plot, and the suggested threshold of HOMA-IR for lung function decline was 2.4. As a surrogate marker of insulin resistance, several studies have shown that the cutoff value of HOMA-IR for the risk of developing type 2 diabetes mellitus and metabolic syndrome in the Korean population is approximately 2.5 [22-24]. Our findings, consistent with those of previous studies, indicated that a decline in lung function may be metabolic complication due to the systemic effects of insulin resistance.

There were two possible explanations for the potential pulmonary hazard of insulin resistance. First, chronic low-grade inflammation in adipose tissue contributes to the development of insulin resistance $[25,26]$. Levels of cytokines, such as tumor necrosis factor-alpha (TNF-a) and interleukin-6, are increased with insulin resistance and cause lung fibrosis and inflammation [27, 28]. Second, respiratory muscle weakness is related to insulin resistance. With insulin resistance, TNF- $\alpha$ and interferon-gamma cause muscle wasting through the degeneration of myotubes and modulation of myogenesis $[29,30]$.

In subgroup analysis, age showed a statistically significant effect modification on the association between HOMA-IR and annual change in FEV1. Although HOMA-IR was not associated with annual change in FEV1 in the younger group, increased HOMA-IR was significantly related to decreased FEV1 in the older group ( $P$ for interaction $<0.001$ ).

Insulin resistance is associated with chronic low-grade inflammation [25]. The risk of chronic low-grade inflammation increased with the aging process [31, 32]. Lung function can decline with increased inflammation [33,34]. Therefore, we assumed that increased chronic low-grade inflammation during the aging process may potentiate the metabolic hazard of insulin resistance in lung function decline. In this regard, early intervention to reduce insulin resistance in the elderly population may have a beneficial effect on future lung function preservation.

Several limitations should be considered when interpreting our findings. First, two or fewer additional lung function measurements were performed in this study. Therefore, the rate of change in FEV1 and FVC only reflects short-term changes in lung function. Further studies performing more spirometric tests will be needed to clarify the long-term effect of insulin resistance on lung function. Second, our study was 
conducted in single ethnicity and selected areas. Therefore, the results should be elucidated cautiously in accordance with racial and regional differences. Despite these limitations, our study has several strengths. First, to the best of our knowledge, this is the first study to investigate the association between insulin resistance and lung function using a large-scale prospective cohort based on the general population. Second, we calculated the threshold of HOMA-IR for lung function decline using a nonlinear analytic method. Finally, the interaction between age and insulin resistance to lung function changes was investigated and presented using visualization.

In conclusion, increased insulin resistance was independently associated with a decrease in FEV1 and FVC, particularly in the older population. The potential pulmonary hazard of insulin resistance needs to be confirmed in future interventional studies

\section{Abbreviations}

HOMA-IR: Homeostatic model assessment-insulin resistance; FEV1: Forced expiratory volume in 1 second; FVC: Functional vital capacity; Cl: Confidence interval; BP: Blood pressure; BMI: Body mass index; WBC: White blood cell; $\mathrm{HbA}_{1} \mathrm{c}$ : Hemoglobin $\mathrm{A}_{1} \mathrm{C}$; HDL: High density lipoprotein; CRP: C-reactive protein; eGFR: Estimated glomerular filtration rate; SD: Standard deviation; IQR: interquartile range; LOWESS: Locally weighted scatter-plot smoothing; GAM: Generalized additive model; AIC: Akaike's information criterion; TNF-a: Tumor necrosis factor-alpha

\section{Declarations}

\section{Ethics approval and consent to participate}

Using the Ansan-Ansung cohort, this study was conducted according to the Declaration of Helsinki. The institutional review boards of the Nowon Eulji Medical Center, Eulji University approved the protocol and ethics of the study (Approval Number: 2019-06-014). Participants provided written informed consent, and all data were completely anonymized prior to access.

\section{Consent for publication}

Not applicable.

\section{Availability of data and materials}

The data of our study is fully available when manuscript is accepted for publication.

\section{Competing interests}

All authors have no conflicts of interest to declare.

\section{Funding}


This study was supported by the National Research Foundation of Korea and funded by the Korean government (Grant No: NRF-2016R1A6A3A11933465). The funder had no role in the design and conduct of the study, data curation and analysis, or drafting of the manuscript.

\section{Author's contributions}

S.W.L. conceptualization. S.H.K. data curation/formal analysis. H.S.K. investigation/ methodology. S.H.K. writing - original draft. H.K.M. writing - review and editing. S.W.L. supervision/validation. All authors read and approved the final manuscript.

\section{Acknowledgement}

There is no acknowledgement to declare.

\section{References}

1. Zheng Y, Ley SH, Hu FB: Global aetiology and epidemiology of type 2 diabetes mellitus and its complications. Nature Reviews Endocrinology 2018, 14(2):88.

2. Susan van D, Beulens JW, Yvonne T. van der S, Grobbee DE, Nealb B: The global burden of diabetes and its complications: an emerging pandemic. European Journal of Cardiovascular Prevention \& Rehabilitation 2010, 17(1_suppl):s3-s8.

3. Klein O, Krishnan J, Glick S, Smith LJ: Systematic review of the association between lung function and Type 2 diabetes mellitus. Diabetic medicine 2010, 27(9):977-987.

4. Yeh H-C, Punjabi NM, Wang N-Y, Pankow JS, Duncan BB, Cox CE, Selvin E, Brancati FL: Crosssectional and prospective study of lung function in adults with type 2 diabetes: the Atherosclerosis Risk in Communities (ARIC) study. Diabetes care 2008, 31(4):741-746.

5. Khateeb J, Fuchs E, Khamaisi M: Diabetes and lung disease: a neglected relationship. The Review of Diabetic Studies: RDS 2019, 15:1.

6. Mamillapalli C, Tentu R, Jain NK, Bhandari R: COPD and type 2 diabetes. Current Respiratory Medicine Reviews 2019, 15(2):112-119.

7. Enomoto T, Usuki J, Azuma A, Nakagawa T, Kudoh S: Diabetes mellitus may increase risk for idiopathic pulmonary fibrosis. Chest 2003, 123(6):2007-2011.

8. Perez MK, Piedimonte G: Metabolic asthma: is there a link between obesity, diabetes, and asthma? Immunology and Allergy Clinics 2014, 34(4):777-784.

9. Gallagher EJ, LeRoith D, Karnieli E: The metabolic syndrome-from insulin resistance to obesity and diabetes. Endocrinology and metabolism clinics of North America 2008, 37(3):559-579.

10. Ginsberg HN: Insulin resistance and cardiovascular disease. The Journal of clinical investigation 2000, 106(4):453-458.

11. Kim B, Feldman EL: Insulin resistance in the nervous system. Trends in Endocrinology \& Metabolism 2012, 23(3):133-141. 
12. De Cosmo S, Menzaghi C, Prudente S, Trischitta V: Role of insulin resistance in kidney dysfunction: insights into the mechanism and epidemiological evidence. Nephrology Dialysis Transplantation 2013, 28(1):29-36.

13. Sharma G, Goodwin J: Effect of aging on respiratory system physiology and immunology. Clinical interventions in aging 2006, 1(3):253.

14. Skloot GS: The effects of aging on lung structure and function. Clinics in geriatric medicine 2017, 33(4):447-457.

15. Kim Y, Han B-G, Group K: Cohort profile: the Korean genome and epidemiology study (KoGES) consortium. International journal of epidemiology 2017, 46(2):e20-e20.

16. Wallace TM, Levy JC, Matthews DR: Use and abuse of HOMA modeling. Diabetes care 2004, 27(6):1487-1495.

17. Choi JK, Paek D, Lee JO: Normal predictive values of spirometry in Korean population. Tuberculosis and Respiratory Diseases 2005, 58(3):230-242.

18. Levey AS, Stevens LA, Schmid CH, Zhang Y, Castro III AF, Feldman HI, Kusek JW, Eggers P, Van Lente $\mathrm{F}, \mathrm{Greene} \mathrm{T}$ : A new equation to estimate glomerular filtration rate. Annals of internal medicine 2009, 150(9):604-612.

19. Anderson D, Burnham K: Model selection and multi-model inference. Second NY: Springer-Verlag 2004, 63(2020):10.

20. Lawlor D, Ebrahim S, Smith GD: Associations of measures of lung function with insulin resistance and type 2 diabetes: findings from the British Women's Heart and Health Study. Diabetologia 2004, 47(2):195-203.

21. Sagun G, Gedik C, Ekiz E, Karagoz E, Takir M, Oguz A: The relation between insulin resistance and lung function: a cross sectional study. BMC pulmonary medicine 2015, 15(1):139.

22. Kim B, Choi HY, Kim W, Ahn C, Lee J, Kim JG, Kim J, Shin H, Yu JM, Moon S: The cut-off values of surrogate measures for insulin resistance in the Korean population according to the Korean Genome and Epidemiology Study (KOGES). PLoS One 2018, 13(11):e0206994.

23. Yun K-J, Han K, Kim MK, Park Y-M, Baek K-H, Song K-H, Kwon H-S: Insulin resistance distribution and cut-off value in Koreans from the 2008-2010 Korean National Health and Nutrition Examination Survey. PLOS One 2016, 11(4):e0154593.

24. Baek JH, Kim H, Kim KY, Jung J: Insulin resistance and the risk of diabetes and dysglycemia in Korean general adult population. Diabetes \& metabolism journal 2018, 42(4):296-307.

25. De Luca C, Olefsky JM: Inflammation and insulin resistance. FEBS letters 2008, 582(1):97-105.

26. Zatterale F, Longo M, Naderi J, Raciti GA, Desiderio A, Miele C, Beguinot F: Chronic Adipose Tissue Inflammation Linking Obesity to Insulin Resistance and Type 2 Diabetes. Front Physiol 2020, 10:1607-1607.

27. Lundblad LK, Thompson-Figueroa J, Leclair T, Sullivan MJ, Poynter ME, Irvin CG, Bates JH: Tumor necrosis factor- $a$ overexpression in lung disease: a single cause behind a complex phenotype. 
American journal of respiratory and critical care medicine 2005, 171(12):1363-1370.

28. Rincon M, Irvin CG: Role of IL-6 in asthma and other inflammatory pulmonary diseases. International journal of biological sciences 2012, 8(9):1281.

29. Laghi F, Tobin MJ: Disorders of the respiratory muscles. American journal of respiratory and critical care medicine 2003, 168(1):10-48.

30. Londhe P, Davie JK: Gamma interferon modulates myogenesis through the major histocompatibility complex class II transactivator, CIITA. Mol Cell Biol 2011, 31(14):2854-2866.

31. Fagiolo U, Cossarizza A, Scala E, Fanales-Belasio E, Ortolani C, Cozzi E, Monti D, Franceschi C, Paganelli R: Increased cytokine production in mononuclear cells of healthy elderly people. European journal of immunology 1993, 23(9):2375-2378.

32. Krabbe KS, Pedersen M, Bruunsgaard H: Inflammatory mediators in the elderly. Experimental gerontology 2004, 39(5):687-699.

33. Jiang R, Burke GL, Enright PL, Newman AB, Margolis HG, Cushman M, Tracy RP, Wang Y, Kronmal RA, Barr RG: Inflammatory markers and longitudinal lung function decline in the elderly. American journal of epidemiology 2008, 168(6):602-610.

34. Hancox RJ, Poulton R, Greene JM, Filsell S, McLachlan CR, Rasmussen F, Taylor DR, Williams MJ, Williamson A, Sears MR: Systemic inflammation and lung function in young adults. Thorax 2007, 62(12):1064-1068.

\section{Figures}


10,030 subjects enrolled in Ansan-Ansung cohort study

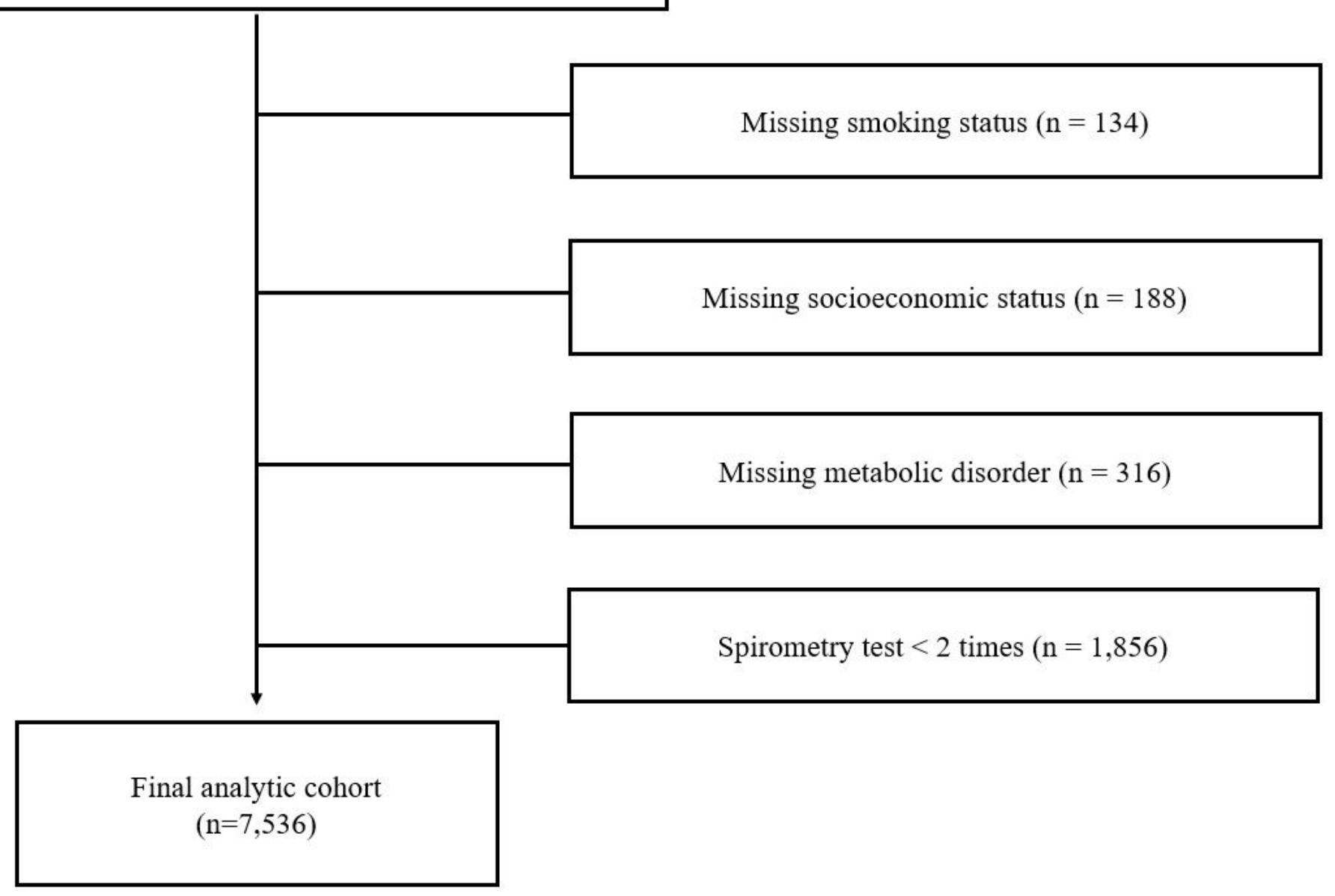

Figure 1

Flow chart of the study subject selection
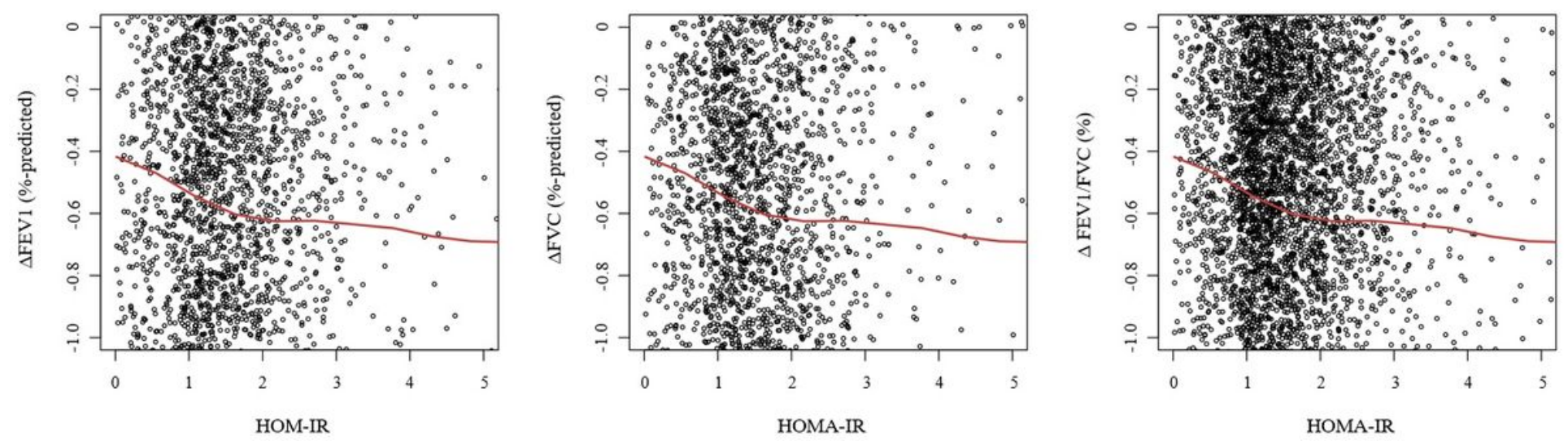

Figure 2

Association between HOMA-IR and lung function. The red line represented the LOWESS regression curve. Abbreviations: HOMA-IR, homeostatic model assessment-insulin resistance; LOWESS, locally weighted 
A. HOMA-IR and annual FEV1 change

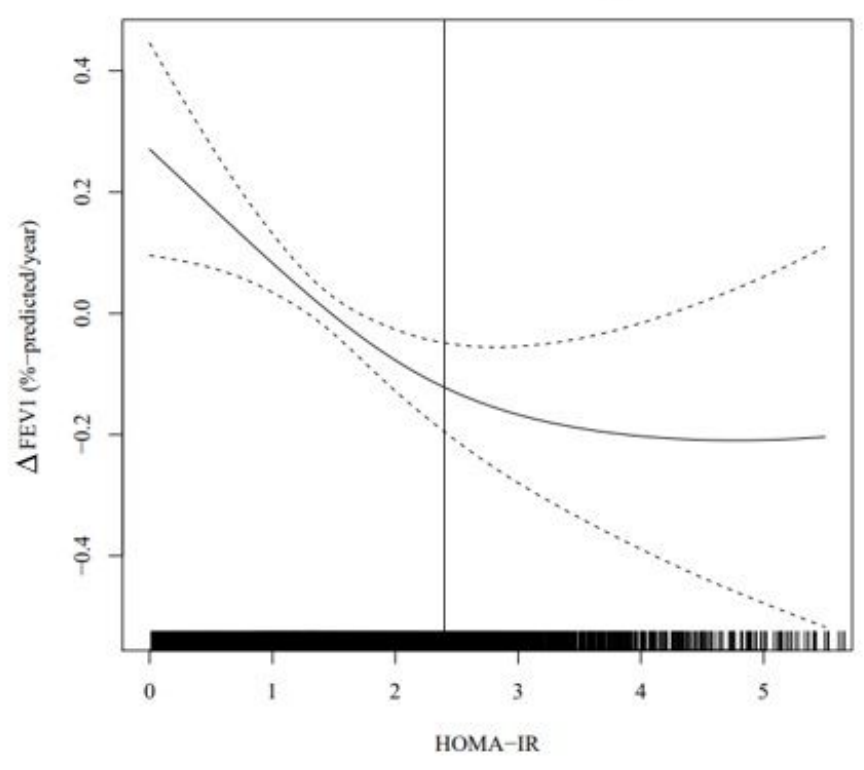

B. HOMA-IR and annual FVC change

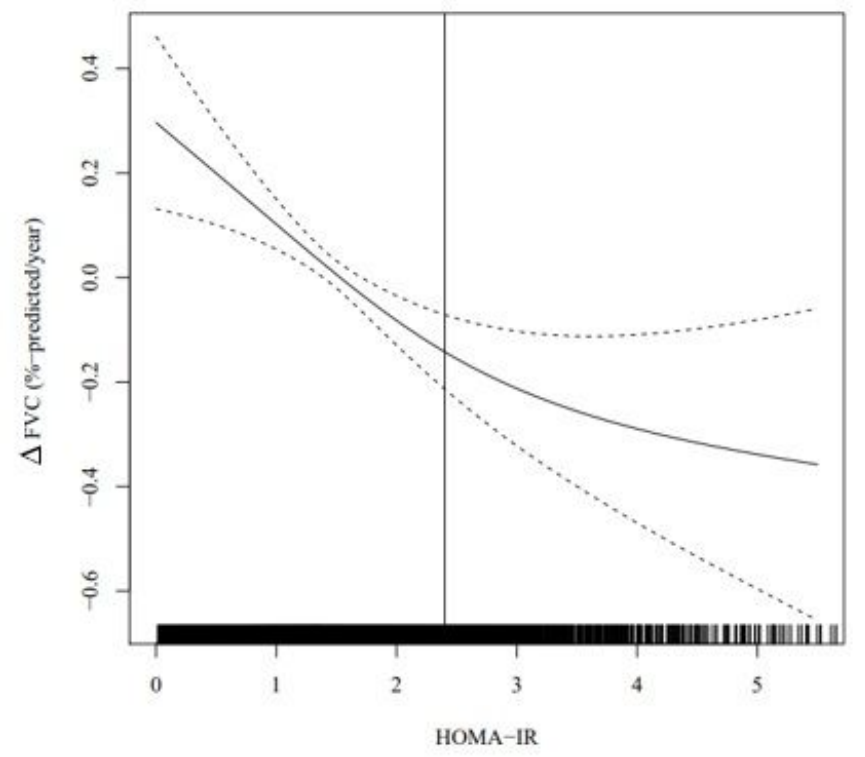

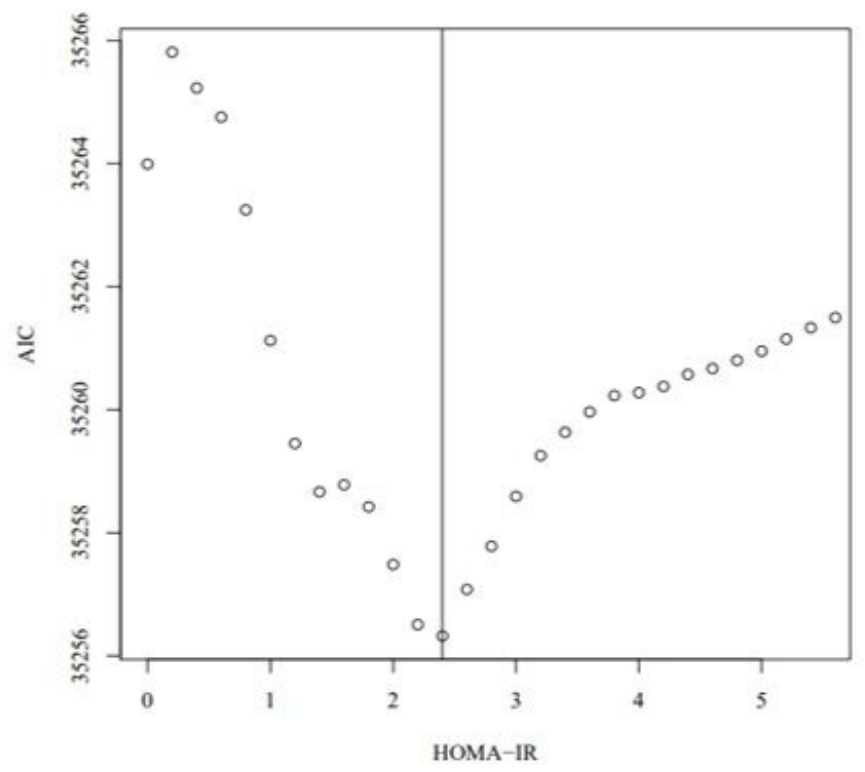

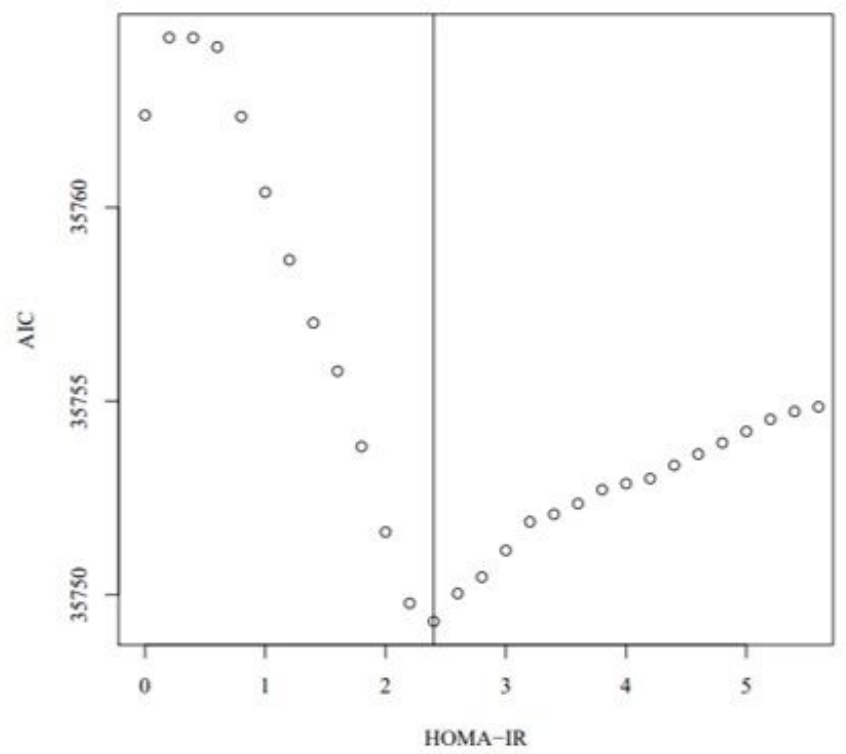

\section{Figure 3}

GAM plot between HOMA-IR and annual lung function change. The dashed lines indicate $95 \%$ Cls for values of smoothed changes in FEV1 and FVC, using the multivariate GAM analysis after adjusting for age, sex, high income, college graduate, smoking status, BMI, waist circumference, systolic and diastolic BP, triglyceride, HDL cholesterol, eGFR, WBC count, hemoglobin and CRP levels. Abbreviations: GAM, general additive model; HOMA-IR, homeostatic model assessment-insulin resistance; $\mathrm{Cl}$, confidence interval; FEV1, forced expiratory volume in 1 second; FVC, forced vital capacity; BMI, body mass index; BP, blood pressure; HDL, high density lipoprotein; eGFR, estimated glomerular filtration rate; WBC, white blood cell; CRP, C-reactive protein 


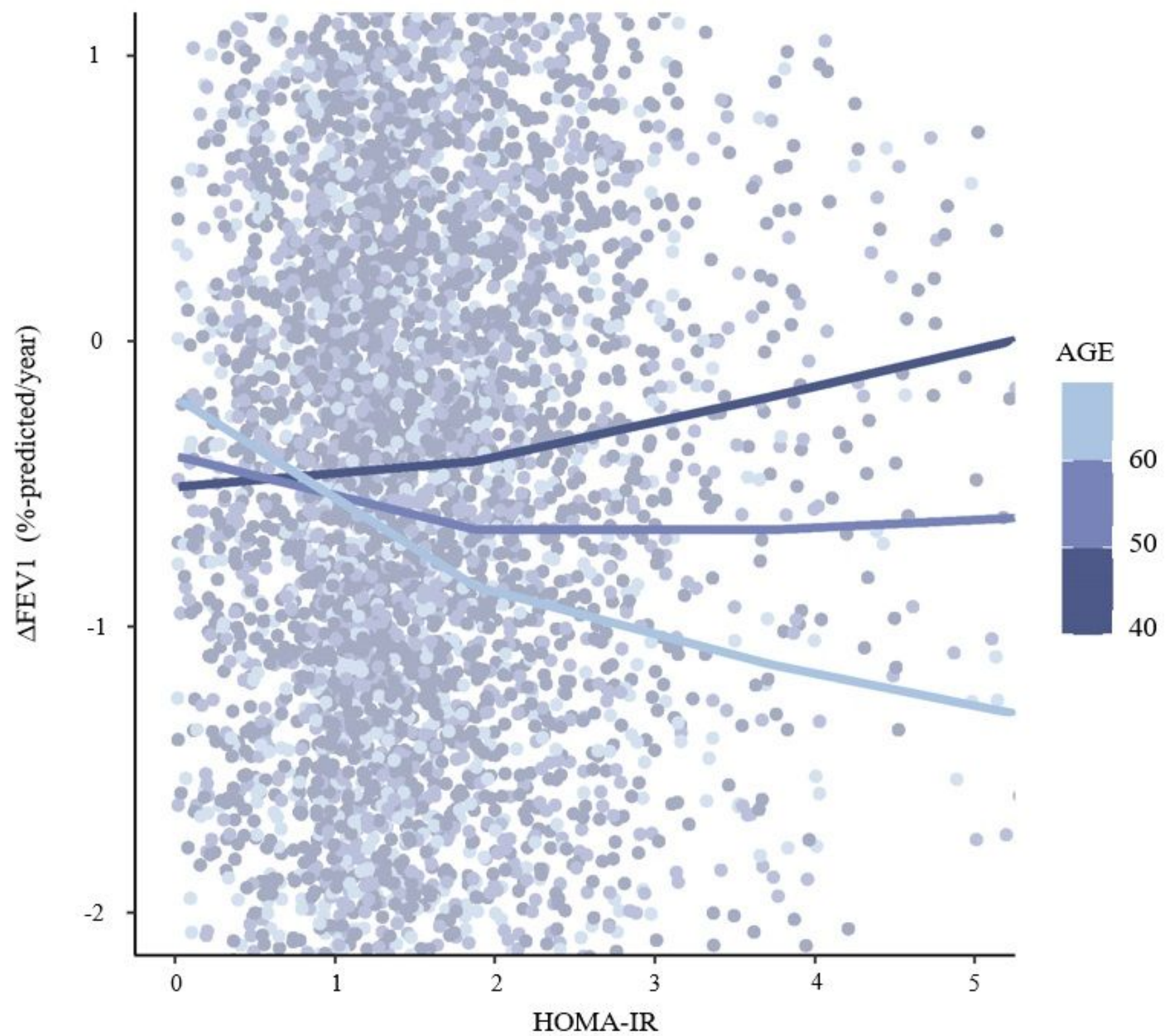

Figure 4

LOWESS regression plot with interaction for the effect modification of age on the association between HOMA-IR and annual FEV1 change. Solid lines represented the univariate LOWESS regression curves according to the age group. The blue, dark blue, and light blue lines represented lines of mean age (52 years), minus one SD (43 years) and plus one SD (60 years), respectively. Abbreviations: LOWESS, locally weighted scatter-plot smoothing; HOMA-IR, homeostatic model assessment-insulin resistance; FEV1, forced expiratory volume in 1 second; SD, standard deviation

\section{Supplementary Files}

This is a list of supplementary files associated with this preprint. Click to download. 
- KoGESbaselineCoreQuestionnaire.pdf 